\title{
Impact of age, sex and medical history on adverse reactions to the first and second dose of BNT162b2 mRNA COVID-19 vaccine in Japan: a cross-sectional study
}

Ryuta Urakawa ${ }^{1,2^{*}} \mathbb{0}$, Emiko Tanaka Isomura ${ }^{3}$, Kazuhide Matsunaga ${ }^{4}$, Kazumi Kubota ${ }^{5}$ and Miho Ike ${ }^{6}$

\begin{abstract}
Background: Vaccines for coronavirus disease 2019 (COVID-19) caused by severe acute respiratory syndrome coronavirus 2 (SARS-CoV-2) are being promoted worldwide. In this study, we analyzed the relationship between adverse reactions and the profile of vaccinated recipients.

Methods: Vaccinated subjects who received two doses of BNT162b2 between May 17 and June 11, 2021, at Osaka University Dental Hospital were included in this study. Adverse reactions and profiles were collected by questionnaires, and the relationship between the presence of adverse reactions and the profiles of the vaccinated persons was analyzed by logistic regression analysis. The correlation between the severity of adverse reactions and age was analyzed by Spearman's rank correlation.

Results: Logistic regression analysis showed that, for many kinds of adverse reactions, the incidence was significantly higher in females than in males and in younger than in older people. There was a very weak but significant negative correlation between age and the severity of many kinds of adverse reactions. The relationship between sex and the incidence of each adverse reaction was significant for injection site reactions and fatigue in the first vaccination, whereas significant relationships were found for fatigue, chills, fever, arthralgia, myalgia and headache in the second vaccination, all of which were clearly more likely to occur in females.
\end{abstract}

Conclusion: Adverse reactions to BNT162b2 were found to be more frequent and more intense in females and younger people in Japan, especially after the second vaccination.

Keywords: COVID-19, SARS-CoV-2, Vaccination, Adverse effect, Correlation

\section{Introduction}

The pandemic of coronavirus disease 2019 (COVID-19) caused by severe acute respiratory syndrome coronavirus 2 (SARS-CoV-2) is still mutating and spreading all over the world, leading to severe infections and deaths

\footnotetext{
*Correspondence: urakawa-r@office.osaka-u.ac.jp

1 Department of Pharmacy, Osaka University Dental Hospital, 1-8

Yamada-oka, Suita, Osaka 565-0871, Japan

Full list of author information is available at the end of the article
}

[1]. SARS-CoV-2 is transmitted by respiratory droplets, by aerosol particles, by direct contact with humans, or by indirect contact via contaminated objects [2-4]. COVID-19 causes various symptoms such as fever or chills, cough, shortness of breath or difficulty breathing, fatigue, muscle or body aches, headache, loss of taste or smell, sore throat, congestion or runny nose, nausea or vomiting, and diarrhea. In severe cases, death occurs mainly due to septic shock and multi-organ failure [5-7]. Because COVID-19 is infectious even before the onset 
of disease [8] and because a substantial proportion of infected people may be asymptomatic, infected people with no symptoms at all can be a potential source of infection [9].

While there are effective measures to prevent the spread of COVID-19, such as wearing masks, hand hygiene, and maintaining social distance [10-12], vaccination is a very effective way to prevent infection by acquiring antibodies against SARS-CoV-2. BioNTech started a first-in-human study of BNT162b1 (BNT162-01 trial) in Germany in April 2020 [13], and shortly thereafter Pfizer started a phase $1 / 2 / 3$ study of BNT162b2 (C4591001 clinical trial) in the United States [14]. BNT162b2 was approved by the Medicines and Healthcare products Regulatory Agency (MHRA) in United Kingdom on December 2, 2020, and the world's first vaccination with the licensed COVID-19 vaccine after clinical trials began on December 8, 2020. Since then, various vaccines against SARS-CoV-2 have been approved worldwide, including mRNA-1273 from Moderna/the Vaccine Research Center at the National Institute of Allergy and Infectious Diseases (NIAID), which is an mRNA vaccine similar to BNT162b2 [15]; viral vector vaccines such as ChAdOx1 from Oxford University/AstraZeneca [16] and Ad26.COV2.S from Johnson and Johnson [17]; and inactivated vaccines such as Sinovac's CoronaVac [18]. Various other vaccines against SARS-CoV-2 have been approved and are being administered worldwide.

The COVID-19 vaccine is the world's first mRNAbased vaccine deployed for primary prevention of infectious disease in humans, and its safety, efficacy and effectiveness are still being discussed by researchers. A recent study of self-reported adverse reactions to BNT162b2 in health care workers showed that although there are a variety of adverse reactions, most are not lifethreatening and are well tolerated [19]. The results of other studies also supportsafety, efficacy and effectiveness $[14,20,21]$. However, data focusing on which vaccine recipients are most likely to have adverse reactions is limited and remains to be clarified.

Here, we hypothesized that the incidence and severity of BNT162b2 adverse reactions would vary depending on the profile of the vaccine recipient. In this study, we analyzed the profile of adverse reactions after vaccination and the profile of vaccine recipients using a self-reported adverse reaction questionnaire among vaccine recipients who received BNT162b2 at the Osaka University Dental Hospital.

\section{Methods}

\section{Research subjects}

All vaccinated hospital staffs who received the first dose of BNT162b2 between May 17 and May 21, 2021, and the second dose between June 7 and June 11, 2021, at the Osaka University Dental Hospital were included in this study. Among the subjects, those who did not submit the adverse reaction questionnaire and those who did not complete the confirmation of research consent column provided in the questionnaire were excluded from the study.

\section{Methods for investigating adverse reactions and vaccine recipient profiles}

The questionnaire included columns for sex, age, study consent, current medical history, and presence and severity of adverse reactions. The questionnaire was anonymous. The current medical history included entries for heart disease, kidney disease, liver disease, blood disorders, blood coagulation system disorders, immunodeficiency, and others. The items of adverse reactions were injection site reaction, fatigue, chills, fever, arthralgia, myalgia, headache, diarrhea, nausea, and vomiting, and were prepared with reference to the severity of the Common Terminology Criteria for Adverse Events (CTCAE) Version 5.0. The results of the survey were collected from survey forms deposited in a collection box and from answers to a questionnaire posted on the Web.

\section{Statistical analysis}

Adverse reactions after the first and second doses of vaccine were compared by Wilcoxon's signed rank test. Univariate logistic regression analysis was performed with age or sex as independent variables and the presence or absence of various adverse reactions at the first and second time as dependent variables. Multivariate logistic regression analysis was then performed with age, sex, and previous medical history as covariates. In addition, Spearman's rank correlation coefficient was performed to verify the relationship between age and the severity of each adverse reaction. All statistics were performed with IBM SPSS Statistics 26, and a two-tailed test with $\mathrm{p}<0.05$ was considered a significant difference.

\section{Ethical review}

This study was conducted under the approval of the Ethical Review Committee of Osaka University Dental Hospital (Approval No. R3-E11).

\section{Results}

827 hospital staffs (381 males and 446 females) received two doses of BNT162b2 vaccine. There were no staffs who received only one dose. A total of 460 vaccine recipients consented to the study and completed the questionnaire (participation rate: $55.6 \%$ ). Of these responses, 458 questionnaires with no omissions were included in this study (valid response rate: 99.6\%). The background of the 
study subjects is shown in Table 1 . The results of MannWhitney U test showed that there was no statistically significant difference in age between males and females $(\mathrm{p}=0.74)$.

A comparison of adverse reactions after the first and second doses is shown in Table 2. There was no significant difference in diarrhea, but there were significant differences in other adverse reactions (i.e., injection site reaction, fatigue, chills, fever, arthralgia, myalgia, headache, and nausea) between the first and second doses.

The results of the univariate logistic regression analysis of the association between age or sex and the presence of adverse reactions are shown in Table 3. The results of multivariate logistic regression analysis with age, sex, and previous medical history as covariates are shown in Table 4. For many adverse reactions, females were found to have a significantly higher incidence of adverse reactions than males. Similarly, the incidence of many adverse reactions was found to be significantly higher in younger people. After adjusting for age, sex, and history, injection site reaction, chills, arthralgia, headache, and

Table 1 Background of the research subjects $(N=458)$

\begin{tabular}{ll}
\hline Mean age (SD, range) & $38.9(12.8,19-77)$ \\
All & \\
Sex & $195(42.6)$ \\
$\quad$ Male number (\%) & $263(57.4)$ \\
$\quad$ Female number (\%) & \\
Medical history & $54(11.8)$ \\
$\quad$ Yes (\%) & $404(88.2)$ \\
No (\%)
\end{tabular}

Medical history was identified as heart disease, kidney disease, liver disease, blood disorders, blood coagulation system disorders, immunodeficiency, and others in this study nausea were significantly more likely to occur in younger participants (odds ratio (OR) 0.72, 0.31, 0.77, 0.76, and 0.64 , respectively) and injection site reaction and fatigue were significantly more likely to occur in females (OR 1.71 and 1.57 , respectively) after the first dose. Similarly, after the second dose, injection site reaction, fatigue, chills, fever, arthralgia, myalgia, headache, diarrhea, and nausea were significantly more likely to occur in younger patients (OR 0.85, 0.83, 0.76, 0.74, 0.82, 0.77, 0.77, 0.47, and 0.70 , respectively), and fatigue, chills, fever, arthralgia, myalgia, and headache were significantly more likely to occur in females (OR 1.74, 2.34, 1.79, 1.88, 1.88, and 2.27 , respectively).

The correlation between age and the severity of each adverse reaction is shown in Table 5 . Weak but significant negative correlations with age were detected for injection site reaction, chills, fever, arthralgia, and headache after the first vaccination and for injection site reaction, fatigue, fever, arthralgia, myalgia, headache, diarrhea, and nausea after the second vaccination.

\section{Discussion}

Various types of vaccines against COVID-19 have been developed and are being administered around the world. In Japan, Pfizer's BNT162b2 was approved in February 2021, and vaccinations began for healthcare workers. Subsequently, mRNA-1273 and AZD1222 were approved in May 2021 and, together with BNT162b2, have been promoted for vaccination of both healthcare workers and the public. In Japan, the initial target age group for vaccination was 18 years and older, but in July 2021, the indication was expanded to include children 12 years and older, as the efficacy of the vaccine in children 12 years and older was

Table 2 Severity of adverse reactions after the first and second vaccinations

\begin{tabular}{|c|c|c|c|c|c|}
\hline Severity & $\begin{array}{l}\text { Grade } 0 \\
\text { First dose/second dose } \\
\text { n (\%) }\end{array}$ & $\begin{array}{l}\text { Grade } 1 \\
\text { First dose/second dose } \\
\text { n (\%) }\end{array}$ & $\begin{array}{l}\text { Grade } 2 \\
\text { First dose/second dose } \\
\text { n (\%) }\end{array}$ & $\begin{array}{l}\text { Grade } 3 \\
\text { First dose/second dose } \\
\text { n(\%) }\end{array}$ & $p$ value \\
\hline Injection site reaction & $102(22.3) / 168(36.7)$ & $231(50.4) / 190(41.5)$ & 118 (25.8)/95 (20.7) & $7(1.5) / 5(1.1)$ & $<0.01$ \\
\hline Fatigue & $287(62.7) / 201(43.9)$ & $120(26.2) / 90(19.7)$ & $46(10.0) / 139(30.3)$ & $5(1.1) / 28(6.1)$ & $<0.01$ \\
\hline Chills & $447(97.6) / 389(84.9)$ & $9(2.0) / 48(10.5)$ & $2(0.4) / 21(4.6)$ & $0 / 0$ & $<0.01$ \\
\hline Fever & $446(97.4) / 346(75.5)$ & $12(2.6) / 102(22.3)$ & $0 / 10(2.2)$ & $0 / 0$ & $<0.01$ \\
\hline Arthralgia & $339(87.1) / 318$ (69.4) & $39(8.5) / 67(14.6)$ & $16(3.5) / 61(13.3)$ & $4(0.9) / 12(2.6)$ & $<0.01$ \\
\hline Myalgia & $391(85.4) / 361$ (78.8) & $39(8.5) / 48(10.5)$ & $25(5.5) / 41(9.0)$ & $3(0.7) / 8(1.7)$ & 0.04 \\
\hline Headache & $366(79.9) / 266(58.1)$ & $52(11.4) / 79(17.2)$ & $36(7.9) / 90(19.7)$ & $4(0.9) / 23(5.0)$ & $<0.01$ \\
\hline Diarrhea & $455(97.2) / 439$ (95.9) & $11(2.4) / 16(3.5)$ & $0 / 2(0.4)$ & $2(0.4) / 1(0.2)$ & 0.35 \\
\hline Nausea & $433(94.5) / 407$ (88.9) & $18(3.9) / 23(5.0)$ & $7(1.5) / 27(5.9)$ & $0 / 1(0.2)$ & $<0.01$ \\
\hline Vomiting & $453(98.9) / 447$ (97.6) & $3(0.7) / 9(2.0)$ & $2(0.4) / 1(0.2)$ & $0 / 1(0.2)$ & 0.22 \\
\hline
\end{tabular}

Values are number of adverse effect after first vaccination/second vaccination. Grade is the severity of each adverse reaction with reference to CTCAE Version 5.0. Chisquare test was performed to examine the difference between the first and second adverse reactions 
Table 3 Effect of age or sex on the presence of each adverse reaction

\begin{tabular}{|c|c|c|c|c|}
\hline & \multicolumn{2}{|l|}{ Age } & \multicolumn{2}{|l|}{ Sex } \\
\hline & First vaccination & Second vaccination & First vaccination & Second vaccination \\
\hline & OR $(95 \% \mathrm{Cl})$ & OR $(95 \% \mathrm{Cl})$ & OR $(95 \% \mathrm{Cl})$ & OR $(95 \% \mathrm{Cl})$ \\
\hline Injection site reaction & $0.75(0.63-0.88)^{* *}$ & $0.85(0.73-0.98)^{*}$ & $1.72(1.10-2.67)^{*}$ & $1.38(0.94-2.03)$ \\
\hline Fatigue & $0.90(0.78-1.05)$ & $0.84(0.73-0.97)^{*}$ & $1.58(1.07-2.33)^{*}$ & $1.75(1.20-2.55)^{* *}$ \\
\hline Chills & $0.30(0.12-0.76)^{*}$ & $0.76(0.61-0.95)^{*}$ & $0.41(0.12-1.44)$ & $2.37(1.33-4.20)^{* *}$ \\
\hline Fever & $0.52(0.28-0.98)^{*}$ & $0.75(0.62-0.90)^{* *}$ & $0.36(0.11-1.22)$ & $1.80(1.15-2.81)^{*}$ \\
\hline Arthralgia & $0.80(0.63-1.01)$ & $0.83(0.71-0.98)^{*}$ & $1.01(0.58-1.76)$ & $1.88(1.24-2.86)^{* *}$ \\
\hline Myalgia & $0.86(0.70-1.07)$ & $0.79(0.65-0.95)^{*}$ & $1.39(0.81-2.38)$ & $1.88(1.17-3.03)^{* *}$ \\
\hline Headache & $0.77(0.63-0.93)^{* *}$ & $0.79(0.68-0.92)^{* *}$ & $1.60(0.99-2.58)$ & $2.27(1.54-3.34)^{* *}$ \\
\hline Diarrhea & $0.77(0.47-1.25)$ & $0.55(0.33-0.89)^{*}$ & $0.86(0.28-2.60)$ & $0.82(0.33-2.05)$ \\
\hline Nausea & $0.66(0.45-0.97)^{*}$ & $0.73(0.56-0.94)^{*}$ & $1.34(0.58-3.10)$ & $1.55(0.84-2.87)$ \\
\hline Vomiting & $0.54(0.21-1.40)$ & $0.82(0.49-1.36)$ & $1.11(0.18-6.73)$ & $1.31(0.38-4.52)$ \\
\hline Any adverse event & $0.69(0.56-0.85)^{* *}$ & $0.64(0.52-0.80)^{* *}$ & $2.13(1.20-3.75)^{* *}$ & $2.15(1.21-3.83)^{* *}$ \\
\hline
\end{tabular}

Logistic regression was performed. $O R$ odds ratio, $C l$ confidence interval. ${ }^{*} p<0.05,{ }^{* *} p<0.01$

OR and $95 \% \mathrm{Cl}$ of age show ratio per 10 years. OR and $95 \% \mathrm{Cl}$ of Sex show ratio of female to male

Table 4 Effect of age, sex, and medical history on the presence of each adverse reaction

\begin{tabular}{|c|c|c|c|c|c|c|}
\hline & \multicolumn{2}{|l|}{ Age } & \multicolumn{2}{|l|}{ Sex } & \multicolumn{2}{|l|}{ Medical history } \\
\hline & First vaccination & Second vaccination & First vaccination & Second vaccination & First vaccination & Second vaccination \\
\hline & OR $(95 \% \mathrm{Cl})$ & OR $(95 \% \mathrm{Cl})$ & OR $(95 \% \mathrm{Cl})$ & OR $(95 \% \mathrm{Cl})$ & OR $(95 \% \mathrm{Cl})$ & OR $(95 \% \mathrm{Cl})$ \\
\hline Injection site reaction & $0.72(0.60-0.86)^{* *}$ & $0.85(0.72-0.99)^{*}$ & $1.71(1.09-2.68)^{*}$ & $1.36(0.93-2.01)$ & $1.86(0.86-4.00)$ & $1.13(0.61-2.11)$ \\
\hline Fatigue & $0.90(0.77-1.05)$ & $0.83(0.71-0.97)^{*}$ & $1.57(1.06-2.32)^{*}$ & $1.74(1.19-2.54)^{* *}$ & $1.17(0.63-2.17)$ & $1.29(0.70-2.38)$ \\
\hline Chills & $0.31(0.12-0.82)^{*}$ & $0.76(0.60-0.97)^{*}$ & $0.41(0.12-1.45)$ & $2.34(1.32-4.17)^{* *}$ & N/A & $0.94(0.37-2.39)$ \\
\hline Fever & $0.57(0.30-1.09)$ & $0.74(0.61-0.89)^{* *}$ & $0.35(0.10-1.20)$ & $1.79(1.13-2.82)^{*}$ & N/A & $1.27(0.61-2.61)$ \\
\hline Arthralgia & $0.77(0.60-0.98)^{*}$ & $0.82(0.69-0.97)^{*}$ & $1.00(0.57-1.75)$ & $1.88(1.24-2.87)^{* *}$ & $1.62(0.69-3.82)$ & $1.40(0.73-2.69)$ \\
\hline Myalgia & $0.84(0.67-1.05)$ & $0.77(0.63-0.94)^{* *}$ & $1.39(0.81-2.39)$ & $1.88(1.16-3.04)^{*}$ & $1.50(0.67-3.36)$ & $1.51(0.73-3.15)$ \\
\hline Headache & $0.76(0.62-0.93)^{* *}$ & $0.77(0.66-0.91)^{* *}$ & $1.58(0.98-2.57)$ & $2.27(1.53-3.37)^{* *}$ & $1.25(0.58-2.71)$ & $1.37(0.73-2.57)$ \\
\hline Diarrhea & $0.78(0.47-1.28)$ & $0.47(0.28-0.79)^{* *}$ & $0.85(0.28-2.56)$ & $0.80(0.31-2.03)$ & $0.81(0.10-6.69)$ & $4.41(1.26-15.43)^{*}$ \\
\hline Nausea & $0.64(0.43-0.95)^{*}$ & $0.70(0.54-0.92)^{*}$ & $1.33(0.57-3.09)$ & $1.54(0.83-2.87)$ & $1.64(0.45-6.03)$ & $1.49(0.57-3.86)$ \\
\hline Vomiting & $0.57(0.22-1.52)$ & $0.77(0.45-1.31)$ & $1.11(0.18-6.74)$ & $1.31(0.38-4.54)$ & $\mathrm{N} / \mathrm{A}$ & $2.29(0.44-11.94)$ \\
\hline Any adverse event & $0.67(0.53-0.83)^{* *}$ & $0.62(0.49-0.78)^{* *}$ & $2.10(1.17-3.75)^{*}$ & $2.11(1.16-3.82)^{*}$ & $2.16(0.81-5.77)$ & $2.30(0.85-6.22)$ \\
\hline
\end{tabular}

Logistic regression was performed. OR odds ratio, $\mathrm{Cl}$ confidence interval. ${ }^{*} \mathrm{p}<0.05,{ }^{* *}<\mathrm{p}<0.01$

OR and $95 \% \mathrm{Cl}$ of age show ratio per 10 years. OR and $95 \% \mathrm{Cl}$ of sex show ratio of female to male. OR and $95 \% \mathrm{Cl}$ of medical history show ratio of those with a medical history to those without. All the statistics were adjusted for age, sex, and medical history

recognized. In addition, the effectiveness of the third vaccination has been recognized overseas, and a third vaccination is planned in Japan as well.

Adverse reactions to the COVID-19 vaccine have been reported frequently around the world and are the subject of ongoing discussion. BNT162b2 was the first COVID-19 vaccine licensed in the world, and reports of various adverse reactions have accumulated since its relatively early stages. The main adverse reactions are injection site reactions, fatigue, headache, and fever. In rare cases, serious side effects such as anaphylactic shock and myocarditis have been reported. However, there is still limited data on which vaccine recipients are most likely to have adverse reactions. Hoffmann et al. stated that adverse reactions in vaccinated persons who received the first dose of BNT162b2 in Germany were less common in persons over 80 years of age and in males [22]. From Korea, Bae et al. reported that there was no sex difference in adverse reactions in vaccinated subjects who received the first dose of BNT162b2, but the incidence was higher in younger age groups [23], and Lee et al. reported that the frequency of adverse reactions in vaccinated subjects 
Table 5 Correlation between age (years) and severity of adverse reaction

\begin{tabular}{lll}
\hline & First vaccination & Second vaccination \\
\hline Injection site reaction & $-0.238^{* *}$ & $-0.163^{* *}$ \\
Fatigue & -0.076 & $-0.108^{*}$ \\
Chills & $-0.140^{* *}$ & -0.091 \\
Fever & $-0.105^{*}$ & $-0.134^{* *}$ \\
Arthralgia & $-0.108^{*}$ & $-0.129^{* *}$ \\
Myalgia & -0.077 & $-0.130^{* *}$ \\
Headache & $-0.132^{* *}$ & $-0.143^{* *}$ \\
Diarrhea & -0.053 & $-0.130^{* *}$ \\
Nausea & -0.087 & $-0.117^{*}$ \\
Vomiting & -0.060 & -0.034 \\
\hline
\end{tabular}

Correlation was measured by Spearman's rank correlation. The values indicate the correlation coefficient. ${ }^{*} p<0.05,{ }^{* *}<p<0.01$

who received the second dose of BNT162b2 was significantly higher in females and that the incidence was lower in older age groups [24].

In this study, we first explored the differences in adverse reactions after the first and second vaccination. As a result, the differences between the first and second vaccination were significant for many adverse reactions, and it was apparent that injection site reactions were more severe after the first vaccination, and fatigue, chills, fever, arthralgia, myalgia, headache, and nausea after the second vaccination. This result may be similar to previous reports that adverse reactions after the second vaccination are more likely to be severe [25]. Logistic regression analysis showed that for most of the adverse reactions, the incidence of adverse reactions was significantly higher in younger people. Similarly, females had a significantly higher incidence of adverse reactions than males. As for the severity of adverse reactions: the younger the vaccinated person, the more severe the adverse reaction(s), after both the first and second vaccination. This result seems to support reports of the existence of age and sex differences in response to the vaccine [26], and previous reports that the COVID-19 vaccine has a stronger immune response in females than in males and in young people than in the elderly [22]. This is probably due to the fact that antibody response to the vaccine is associated with sex hormone levels in both males and females, with females being more affected, as reported in the influenza H1N1 vaccine [27]. In recent study of RNA-sequencing data suggested that some gene expression was a promising target for association with gender-related adverse vaccine events [28]. Also, agerelated result could be explained by immunosenescence which is a series of age-related changes in immune system with changes of the cells of the immune system, the soluble molecules that guide the maintenance and function of the immune system, and the lymphoid organs that coordinate both the maintenance of lymphocytes and the initiation of immune responses [29]. Although efficacy was not verified in this study, Vassilaki et al. reported higher antibody titers in females and younger vaccinated recipients [30]. In addition, a systematic review reported potential sex-related differences in efficacy and safety [31]. Therefore, it is possible that lower doses of vaccination in females and young people may provide equivalent immunity with fewer side effects. As for the medical history, it is widely known that having co-morbidities lead to high risk of developing severe conditions or high mortality rate by COVID-19 infection [32]. On the other hand, to our best knowledge, there is no evidence about the relationship between medical history and adverse effect of BNT162b2. Therefore, we exploratively included medical history as an independent variable in the analysis in this study.

This study has four limitations. The first is that the results of this study were based on a single institution in Japan, which may be affected by racial differences. Since racial differences in immunity have been reported in the past [33], and the efficacy of COVID-19 vaccine is also reported to possibly be influenced by race [34], it cannot be said that the results of this study are necessarily applicable to other races. However, since there are similar reports from other regions with fewer Asians, it is quite possible that the results of this study apply to other races as well [22]. The second is selection bias. Because the questionnaire was anonymous, it was impossible to compare the study subjects with the vaccinated staffs who were decided not to participate in this study. It is possible that some selection bias were exist with the decision to participate in this study. The third is that the adverse reactions in this study were self-reported assessments of severity. Unlike the physician's judgment of severity, this was a subjective evaluation by the vaccine recipient, making it difficult to compare with previous reports of adverse reactions to COVID-19 vaccines. However, as the importance of subjective evaluation in clinical trials has been recognized in recent years, we believe that this data is important. The fourth is sample size. Because this study is an exploratory study to identify factors that influence adverse reactions to vaccines, it is necessary to design a study that takes into account a strong hypothesis-testing analysis method that includes potential interactions and a sample size that can detect rare adverse events as independent variables.

After spreading around the world, COVID-19 has been creating waves of infection because the virus has repeatedly mutated, so that there is no prospect of ending the pandemic in the near future. The COVID-19 vaccine is 
one of the most powerful means of preventing infection, but antibody titers have been shown to decline over time. In addition, since there have been case reports of infection in vaccinated persons who received two doses of the vaccine, it is considered necessary to repeat the vaccination in the future, just as with the influenza vaccine. Therefore, as the results of this study indicate, it is necessary to continue to promote vaccination while also attending to the relatively strong adverse reactions in females and young people.

\section{Conclusion}

This study revealed that adverse reactions to BNT162b2 are more frequent and more intense in females and young people. Therefore, as the results of this study indicate, it is necessary to continue to promote vaccination while acknowledging that females and younger vaccine recipients may possibly experience a higher incidence and/or greater severity of a range of typically transient, flu-like adverse reactions examined in our study. In the future, we hope that data from the third and subsequent vaccinations in Japan and from other countries will provide stronger evidence of differences in efficacy and adverse reactions depending on patient profiles. We also hope that this will lead to the development of more effective vaccinations. Additionally, the proportion of Grade 3 serious adverse reactions due to the vaccine were very low in this study. As COVID-19 vaccination is promoted worldwide, it is expected that the severity and incidence of adverse reactions will change with multiple doses or cross-vaccination with other types of vaccines. It is expected that further research on adverse reactions due to vaccines will be promoted in the future.

\section{Abbreviations}

COVID-19: Coronavirus disease 2019; SARS-CoV-2: Severe acute respiratory syndrome coronavirus 2; MHRA: Medicines and Healthcare products Regulatory Agency; NIAID: National Institute of Allergy and Infectious Diseases; CTCAE: Common Terminology Criteria for Adverse Events; OR: Odds ratio; Cl: Confidence interval.

\section{Acknowledgements}

We thank all staff members at Osaka University Dental Hospital who helped to promote our study.

\section{Authors' contributions}

RU drafted and designed the study; acquired, analyzed, interpreted the data; and drafted the manuscript. ETI, KM, and Ml revised the design of the research and the manuscript. KK analyzed and interpreted the data and revised the manuscript. All authors read and approved the final manuscript.

\section{Funding}

There was no funding granted for this article.

\section{Availability of data and materials}

All data generated or analyzed during this study are included in this published article.

\section{Declarations}

\section{Ethics approval and consent to participate}

This study was conducted in accordance with the Declaration of Helsinki and with the approval of the Ethical Review Committee of Osaka University Dental Hospital (Approval No. R3-E11). Informed consent was obtained from all participants through written explanation and completion of the research consent confirmation column on the questionnaire.

\section{Consent for publication}

Not applicable.

\section{Competing interests}

The authors declare that they have no competing interests.

\section{Author details}

1Department of Pharmacy, Osaka University Dental Hospital, 1-8 Yamada-oka, Suita, Osaka 565-0871, Japan. ${ }^{2}$ Department of Clinical Pharmacy Research and Education, Graduate School of Pharmaceutical Sciences, Osaka University, 1-6 Yamada-oka, Suita, Osaka 565-0871, Japan. ${ }^{3}$ First Department of Oral and Maxillofacial Surgery, Graduate School of Dentistry, Osaka University, 1-8 Yamada-oka, Suita, Osaka 565-0871, Japan. ${ }^{4}$ Second Department of Oral and Maxillofacial Surgery, Graduate School of Dentistry, Osaka University, 1-8 Yamada-oka, Suita, Osaka 565-0871, Japan. ${ }^{5}$ Department of Healthcare Information Management, The University of Tokyo Hospital, 7-3-1 Hongo, Bunkyo-ku, Tokyo 113-8655, Japan. ${ }^{6}$ Nursing Department, Osaka University Dental Hospital, 1-8 Yamada-oka, Suita, Osaka 565-0871, Japan.

Received: 18 November 2021 Accepted: 17 February 2022

Published online: 23 February 2022

\section{References}

1. Coronavirus disease (COVID-19). Weekly epidemiological update and weekly operational update. https://www.who.int/emergencies/diseases/ novel-coronavirus-2019/situation-reports.

2. Jayaweera M, Perera H, Gunawardana B, Manatunge J. Transmission of COVID-19 virus by droplets and aerosols: a critical review on the unresolved dichotomy. Environ Res. 2020;188:109819. https://doi.org/10. 1016/j.envres.2020.109819.

3. Transmission of SARS-CoV-2: implications for infection prevention precautions. https://www.who.int/news-room/commentaries/detail/trans mission-of-sars-cov-2-implications-for-infection-prevention-precautions.

4. Scientific brief: SARS-CoV-2 transmission. https://www.cdc.gov/coron avirus/2019-ncov/science/science-briefs/sars-cov-2-transmission.html.

5. Centers for Disease Control and Prevention. Symptoms of COVID-19. https://www.cdc.gov/coronavirus/2019-ncov/symptoms-testing/sympt oms.html. Updated 22 Feb 2021.

6. Elezkurtaj S, Greuel S, Ihlow J, Michaelis EG, Bischoff P, Kunze CA, Sinn BV, Gerhold M, Hauptmann K, Ingold-Heppner B, Miller F, Herbst H, Corman VM, Martin H, Radbruch H, Heppner FL, Horst D. Causes of death and comorbidities in hospitalized patients with COVID-19. Sci Rep. 2021;11(1):4263. https://doi.org/10.1038/s41598-021-82862-5.

7. Wiersinga WJ, Rhodes A, Cheng AC, Peacock SJ, Prescott HC. Pathophysiology, transmission, diagnosis, and treatment of coronavirus disease 2019 (COVID-19): a review. JAMA. 2020;324(8):782-93. https://doi.org/10.1001/ jama.2020.12839.

8. Tindale LC, Stockdale JE, Coombe M, Garlock ES, Lau WYV, Saraswat M, Zhang L, Chen D, Wallinga J, Colijn C. Evidence for transmission of COVID19 prior to symptom onset. Elife. 2020;9:e57149. https://doi.org/10.7554/ eLife.57149.

9. Al-Sadeq DW, Nasrallah GK. The incidence of the novel coronavirus SARSCoV-2 among asymptomatic patients: a systematic review. Int I Infect Dis. 2020;98:372-80. https://doi.org/10.1016/j.jijd.2020.06.098 (Epub 2020 Jul 2).

10. Coclite D, Napoletano A, Gianola S, Del Monaco A, D’Angelo D, Fauci A, lacorossi L, Latina R, Torre G, Mastroianni CM, Renzi C, Castellini G, lannone P. Face mask use in the community for reducing the spread of 
COVID-19: a systematic review. Front Med (Lausanne). 2021;7:594269. https://doi.org/10.3389/fmed.2020.594269 (eCollection 2020).

11. Veys K, Dockx K, Van Remoortel H, Vandekerckhove P, De Buck E. The effect of hand hygiene promotion programs during epidemics and pandemics of respiratory droplet-transmissible infections on health outcomes: a rapid systematic review. BMC Public Health. 2021;21(1):1745. https://doi.org/10.1186/s12889-021-11815-4

12. Chu DK, AkI EA, Duda S, Solo K, Yaacoub S, Schünemann HJ, COVID-19 Systematic Urgent Review Group Effort (SURGE) Study Authors. Physical distancing, face masks, and eye protection to prevent person-to-person transmission of SARS-CoV-2 and COVID-19: a systematic review and meta-analysis. Lancet. 2020;395(10242):1973-87. https://doi.org/10.1016/ S0140-6736(20)31142-9 (Epub 2020 Jun 1).

13. Mulligan MJ, Lyke KE, Kitchin N, Absalon J, Gurtman A, Lockhart S, Neuzil K, Raabe V, Bailey R, Swanson KA, Li P, Koury K, Kalina W, Cooper D, FontesGarfias C, Shi PY, Türeci Ö, Tompkins KR, Walsh EE, Frenck R, Falsey AR, Dormitzer PR, Gruber WC, Şahin U, Jansen KU. Phase I/II study of COVID-19 RNA vaccine BNT162b1 in adults. Nature. 2020;586(7830):589-93. https:// doi.org/10.1038/s41586-020-2639-4 (Epub 2020 Aug 12).

14. Polack FP, Thomas SJ, Kitchin N, Absalon J, Gurtman A, Lockhart S, Perez JL, Pérez Marc G, Moreira ED, Zerbini C, Bailey R, Swanson KA, Roychoudhury S, Koury K, Li P, Kalina WV, Cooper D, Frenck RW Jr, Hammitt LL, Türeci Ö, Nell H, Schaefer A, Ünal S, Tresnan DB, Mather S, Dormitzer PR, Şahin U, Jansen KU, Gruber WC, C4591001 Clinical Trial Group. Safety and efficacy of the BNT162b2 mRNA Covid-19 vaccine. N Engl J Med. 2020;383(27):2603-15. https://doi.org/10.1056/NEJMoa2034577 (Epub 2020 Dec 10).

15. Baden LR, El Sahly HM, Essink B, Kotloff K, Frey S, Novak R, Diemert D, Spector SA, Rouphael N, Creech CB, McGettigan J, Khetan S, Segall N, Solis J, Brosz A, Fierro C, Schwartz H, Neuzil K, Corey L, Gilbert P, Janes H, Follmann D, Marovich M, Mascola J, Polakowski L, Ledgerwood J, Graham BS, Bennett H, Pajon R, Knightly C, Leav B, Deng W, Zhou H, Han S, Ivarsson M, Miller J, Zaks T, COVE Study Group. Efficacy and safety of the mRNA-1273 SARS-CoV-2 vaccine. N Engl J Med. 2021;384(5):403-16. https://doi.org/10.1056/NEJMoa2035389 (Epub 2020 Dec 30).

16. Voysey M, Clemens SAC, Madhi SA, Weckx LY, Folegatti PM, Aley PK, Angus B, Baillie VL, Barnabas SL, Bhorat QE, Bibi S, Briner C, Cicconi P, Collins AM, Colin-Jones R, Cutland CL, Darton TC, Dheda K, Duncan CJA, Emary KRW, Ewer KJ, Fairlie L, Faust SN, Feng S, Ferreira DM, Finn A, Goodman AL, Green CM, Green CA, Heath PT, Hill C, Hill H, Hirsch I, Hodgson SHC, Izu A, Jackson S, Jenkin D, Joe CCD, Kerridge S, Koen A, Kwatra G, Lazarus R, Lawrie AM, Lelliott A, Libri V, Lillie PJ, Mallory R, Mendes AVA, Milan EP, Minassian AM, McGregor A, Morrison H, Mujadidi YF, Nana A, O'Reilly PJ, Padayachee SD, Pittella A, Plested E, Pollock KM, Ramasamy MN, Rhead S, Schwarzbold AV, Singh N, Smith A, Song R, Snape MD, Sprinz E, Sutherland RK, Tarrant R, Thomson EC, Török ME, Toshner M, Turner DPJ, Vekemans J, Villafana TL, Watson MEE, Williams CJ, Douglas AD, Hill AVS, Lambe T, Gilbert SC, Pollard AJ, Oxford COVID Vaccine Trial Group. Safety and efficacy of the ChAdOx1 nCoV-19 vaccine (AZD1222) against SARS-CoV-2: an interim analysis of four randomised controlled trials in Brazil, South Africa, and the UK. Lancet. 2021;397(10269):99-111. https://doi.org/10.1016/S0140-6736(20)32661-1 (Epub 2020 Dec 8).

17. Sadoff J, Gray G, Vandebosch A, Cárdenas V, Shukarev G, Grinsztejn B, Goepfert PA, Truyers C, Fennema H, Spiessens B, Offergeld K, Scheper G, Taylor KL, Robb ML, Treanor J, Barouch DH, Stoddard J, Ryser MF, Marovich MA, Neuzil KM, Corey L, Cauwenberghs N, Tanner T, Hardt K, Ruiz-Guiñazú J, Le Gars M, Schuitemaker H, Van Hoof J, Struyf F, Douoguih M, ENSEMBLE Study Group. Safety and efficacy of single-dose Ad26.COV2.S vaccine against Covid-19. N Engl J Med. 2021;384(23):2187-201. https://doi.org/ 10.1056/NEJMoa2101544 (Epub 2021 Apr 21)

18. Tanriover MD, Doğanay HL, Akova M, Güner HR, Azap A, Akhan S, Köse Ş, Erdinç FŞ, Akalın EH, Tabak ÖF, Pullukçu H, Batum Ö, Şimşek Yavuz S, Turhan Ö, Yıldırmak MT, Köksal I, Taşova Y, Korten V, Yılmaz G, Çelen MK, Altın S, Çelik I, Bayındır Y, Karaoğlan I, Yılmaz A, Özkul A, Gür H, Unal S, CoronaVac Study Group. Efficacy and safety of an inactivated wholevirion SARS-CoV-2 vaccine (CoronaVac): interim results of a doubleblind, randomised, placebo-controlled, phase 3 trial in Turkey. Lancet. 2021;398(10296):213-22. https://doi.org/10.1016/S0140-6736(21)01429-X (Epub 2021 Jul 8).

19. Kadali RAK, Janagama R, Peruru S, Malayala SV. Side effects of BNT162b2 mRNA COVID-19 vaccine: a randomized, cross-sectional study with detailed self-reported symptoms from healthcare workers. Int J Infect Dis. 2021;106:376-81. https://doi.org/10.1016/j.ijid.2021.04.047 (Epub 2021 Apr 15).

20. Frenck RW Jr, Klein NP, Kitchin N, Gurtman A, Absalon J, Lockhart S, Perez JL, Walter EB, Senders S, Bailey R, Swanson KA, Ma H, Xu X, Koury K, Kalina WV, Cooper D, Jennings T, Brandon DM, Thomas SJ, Türeci Ö, Tresnan DB, Mather S, Dormitzer PR, Sahin U, Jansen KU, Gruber WC, C4591001 Clinical Trial Group. Safety, immunogenicity, and efficacy of the BNT162b2 Covid19 vaccine in adolescents. N Engl J Med. 2021;385(3):239-50. https://doi. org/10.1056/NEJMoa2107456 (Epub 2021 May 27).

21. Dagan N, Barda N, Kepten E, Miron O, Perchik S, Katz MA, Hernán MA Lipsitch M, Reis B, Balicer RD. BNT162b2 mRNA covid-19 vaccine in a nationwide mass vaccination setting. N Engl J Med. 2021;384(15):141223. https://doi.org/10.1056/NEJMoa2101765 (Epub 2021 Feb 24).

22. Hoffmann MA, Wieler HJ, Enders P, Buchholz HG, Plachter B. Age- and sex-graded data evaluation of vaccination reactions after initial injection of the BNT162b2 mRNA vaccine in a local vaccination center in Germany. Vaccines (Basel). 2021;9(8):911. https://doi.org/10.3390/vaccines9080911.

23. Bae S, Lee YW, Lim SY, Lee JH, Lim JS, Lee S, Park S, Kim SK, Lim YJ, Kim EO, Jung J, Kwon HS, Kim TB, Kim SH. Adverse reactions following the first dose of ChAdOX1 nCoV-19 vaccine and BNT162b2 vaccine for healthcare workers in South Korea. J Korean Med Sci. 2021;36(17): e115. https://doi. org/10.3346/jkms.2021.36.e115.

24. Lee YW, Lim SY, Lee JH, Lim JS, Kim M, Kwon S, Joo J, Kwak SH, Kim EO, Jung J, Kwon HS, Kim TB, Kim SH, Bae S. Adverse reactions of the second dose of the BNT162b2 mRNA COVID-19 vaccine in healthcare workers in Korea. J Korean Med Sci. 2021;36(21): e153. https://doi.org/10.3346/jkms. 2021.36.e153.

25. Ossato A, Tessari R, Trabucchi C, Zuppini T, Realdon N, Marchesini F. Comparison of medium-term adverse reactions induced by the first and second dose of mRNA BNT162b2 (Comirnaty, Pfizer-BioNTech) vaccine: a post-marketing Italian study conducted between 1 January and 28 February 2021. Eur J Hosp Pharm. 2021. https://doi.org/10.1136/ejhph arm-2021-002933 (Online ahead of print).

26. Zimmermann $\mathrm{P}$, Curtis $\mathrm{N}$. Factors that influence the immune response to vaccination. Clin Microbiol Rev. 2019;32(2):e00084-18. https://doi.org/10. 1128/CMR.00084-18 (Print 2019 Mar 20).

27. Potluri T, Fink AL, Sylvia KE, Dhakal S, Vermillion MS, Vom Steeg L, Deshpande S, Narasimhan H, Klein SL. Age-associated changes in the impact of sex steroids on influenza vaccine responses in males and females. NPJ Vaccines. 2019;4:29. https://doi.org/10.1038/s41541-019-0124-6 (eCollection 2019).

28. Venkatakrishnan AJ, Praveen Kumar M, Silvert E, Garcia-Rivera E, Szenk M, Suratekar R, Lenehan P, Lindemer E, O'Horo JC, Williams AW, Badley AD, Virk A, Swift MD, Gores GJ, Soundararajan V. Female-male differences in COVID vaccine adverse events have precedence in seasonal flu shots: a potential link to sex-associated baseline gene expression patterns. https://doi.org/10.1101/2021.04.01.21254798.

29. Nikolich-Žugich J. The twilight of immunity: emerging concepts in aging of the immune system. Nat Immunol. 2018;19(1):10-9. https://doi.org/10. 1038/s41590-017-0006-x (Epub 2017 Dec 14).

30. Vassilaki N, Gargalionis AN, Bletsa A, Papamichalopoulos N, Kontou E, Gkika M, Patas K, Theodoridis D, Manolis I, loannidis A, Milona RS, Tsirogianni A, Angelakis E, Chatzipanagiotou S. Impact of age and sex on antibody response following the second Dose of COVID-19 BNT162b2 mRNA vaccine in Greek healthcare workers. Microorganisms. 2021;9(8):1725. https://doi.org/10.3390/microorganisms9081725.

31. Bignucolo A, Scarabel L, Mezzalira S, Polesel J, Cecchin E, Toffoli G. Sex disparities in efficacy in COVID-19 vaccines: a systematic review and meta-analysis. Vaccines (Basel). 2021;9(8):825. https://doi.org/10.3390/ vaccines 9080825 .

32. Xie Y, Wang Z, Liao H, Marley G, Wu D, Tang W. Epidemiologic, clinical, and laboratory findings of the COVID-19 in the current pandemic: systematic review and meta-analysis. BMC Infect Dis. 2020;20(1):640. https://doi.org/ 10.1186/s12879-020-05371-2.

33. Thio CL, Thomas DL, Goedert JJ, Vlahov D, Nelson KE, Hilgartner MW, O'Brien SJ, Karacki P, Marti D, Astemborski J, Carrington M. Racial differences in HLA class II associations with hepatitis C virus outcomes. J Infect Dis. 2001;184(1):16-21. https://doi.org/10.1086/321005 (Epub 2001 May 30). 
34. Liu G, Carter B, Gifford DK. Predicted cellular immunity population coverage gaps for SARS-CoV-2 subunit vaccines and their augmentation by compact peptide sets. Cell Syst. 2021;12(1):102-107.e4. https://doi.org/10 1016/j.cels.2020.11.010 (Epub 2020 Nov 27).

\section{Publisher's Note}

Springer Nature remains neutral with regard to jurisdictional claims in published maps and institutional affiliations.

- fast, convenient online submission

- thorough peer review by experienced researchers in your field

- rapid publication on acceptance

- support for research data, including large and complex data types

- gold Open Access which fosters wider collaboration and increased citations

- maximum visibility for your research: over $100 \mathrm{M}$ website views per year

At $\mathrm{BMC}$, research is always in progress.

Learn more biomedcentral.com/submissions 